\title{
The roles of history and habitat area in the distribution and composition of avian species assemblages in the highlands of Costa Rica
}

\author{
Gilbert Barrantes*, Mariel Yglesias $\dagger$ and Eric J. Fuchs*,1 \\ * Escuela de Biología, Ciudad Universitaria Rodrigo Facio, Universidad de Costa Rica, San José, Costa Rica \\ $\dagger$ Escuela de Posgrado, Centro Agronómico Tropical de Investigación y Enseñanza, CATIE 7170 Cartago, Turrialba 30501, Costa Rica \\ (Accepted 10 January 2011)
}

\begin{abstract}
Bird species assemblages in isolated Neotropical highland mountains have been moulded by the drastic climatic changes that occurred in late Pleistocene. Palynological evidence indicates that after the Pleistocene the highlands of Costa Rica and western Panama became isolated as climate turned gradually more tropical and highland vegetation retreated to the upper elevations of high mountains, forming highland islands. We surveyed birds at 10 representative sites throughout the Costa Rican highlands in order to determine the species composition of highland endemic assemblages. The area of available highland habitat explains $77 \%$ of the variance in species richness of the 36 highland endemics across highland islands, and the composition of these species assemblages have a nested distribution, rather than being independent sets of species on each island. The observed nested pattern is more consistent with a differential extinction model of species assemblages, and less likely to be explained by differential migration. We conclude that the reduction of highland vegetation and the avifauna associated with it, and its subsequent confinement to the summit of high mountains, is a possible explanation for the current distribution of highland endemic species in Costa Rican highland islands.
\end{abstract}

Key Words: endemic birds, extinction, highland islands, nested assemblages, species composition

\section{INTRODUCTION}

The distribution of many highland Neotropical bird species is naturally fragmented as a consequence of past climatic changes (Haffer 1974, Vuilleumier 1970, Weir 2006). The glacial-interglacial cycles of the late Pleistocene, and in particular the climatic shifts after this epoch, had a drastic impact on dispersal, speciation and distribution of the avifauna in the Neotropical highlands. Climatic changes fragmented the more continuous distribution of highland species into a series of disjunct populations restricted to the upper elevations of mountain ranges (Barrantes 2009, Fjeldså 1992, Fjeldså \& Krabbe 1990, Vuilleumier 1970, Weir 2006). By being isolated by topographic discontinuities, species numbers in many of these highland habitat islands (hereafter called highland islands) are affected by a series of factors, in some cases similar to those affecting insular communities, such as island area, distance from a source

\footnotetext{
${ }^{1}$ Corresponding author.

Email: e.j.fuchs@gmail.com/eric.fuchs@ucr.ac.cr
}

of species, distance from other islands, and the interaction of biological processes with the geological dynamics of islands (MacArthur \& Wilson 1967, Nores 1995, Rosenzweig 1995, Simberloff \& Abele 1982, Vuilleumier 1970, Vuilleumier \& Simberloff 1980, Whittaker et al. 2008). Dynamic processes such as local extinction and colonization are expected to be responsible for nonrandom patterns of species composition in a large number of these isolated continental assemblages (Patterson \& Atmar 1986, Patterson \& Brown 1991). Often smaller assemblages contain successive subsets of the species in larger assemblages following a nested pattern (Patterson 1990, Patterson \& Atmar 1986).

Glacial cycles during the late Pleistocene favoured the dispersal of birds from South and North America to the recently formed highland mountains in southern Central America (Barrantes 2009, Hackett 1995. Haffer 1974, Lowell et al. 1995. Pérez-Emán 2005. Prance 1982, Stiles 1983a, Winker \& Pruett 2006). The subsequent switch to a more tropical climate after the Pleistocene, and probably during other interglacial periods during this epoch, caused a contraction of the distribution of highland vegetation in these mountains (Hooghiemstra 
et al. 1992, Islebe et al. 1995, 1996) - and likely also of the avifauna associated with this vegetation to the upper elevations of high mountains (Barrantes 2009). The reduction of the original distribution of highland birds had two major effects. First, it increased the isolation of the highland avifauna of Costa Rica and western Panama from similar South and North American avifauna. Second, it caused a fragmentation within the highlands of Costa Rica and western Panama into highland islands, separated by geographic and climatic barriers (Hackett 1995, Puebla-Olivares et al. 2008).

The effect of this isolation of Costa Rican montane areas has long been recognized on the basis of morphological differences across populations of several avian species (Barrantes \& Sánchez 2000, Slud 1964, Stiles 1983b, 1985). However, the effect of area of available habitat on the number of highland endemic species (e.g. the speciesarea relationship predicted by the Island Biogeography Model) and the effect of past reduction of available habitat on the composition of species assemblages has never been tested using data from Costa Rica's highland islands. To this end, we first tested the hypothesis that area predicts the number of endemic and non-endemic bird species present on highland islands. We then tested the hypothesis that the reduction in highland vegetation that occurred during the last interglacial periods affected the composition of endemic birds on highland islands (e.g. nested distribution vs. independent subsample of species). Finally, we hypothesized that differential species extinction due to reduction of island area had a larger effect on the composition of species on each highland island than dispersal limitation due to barriers between islands.

\section{HIGHLAND ENDEMIC AVIFAUNA}

The Costa Rican-western Panama highland endemic avifauna, as defined by Wolf (1976), consists of those species that occur in the Talamanca mountains above $2400 \mathrm{~m}$. The habitat used by these endemic species includes upper montane forest, subalpine forest, elfin forest and paramo (Barrantes 2005, Barrantes \& Loiselle 2002, Stiles 1983a, 1985). Endemic species are also present in the other three Costa Rican mountain ranges (Central, Tilarán and Guanacaste). In the Talamanca mountain range, the lower limit of some endemic species is below $2400 \mathrm{~m}$ (Stiles \& Skutch 1989), but in all cases their abundance is higher above this altitude (Wolf 1976). Populations of most highland endemic species are naturally fragmented by geographic discontinuities, such as mountain passes and watersheds (Barrantes 2009, Chavarría-Pizarro et al. 2010).

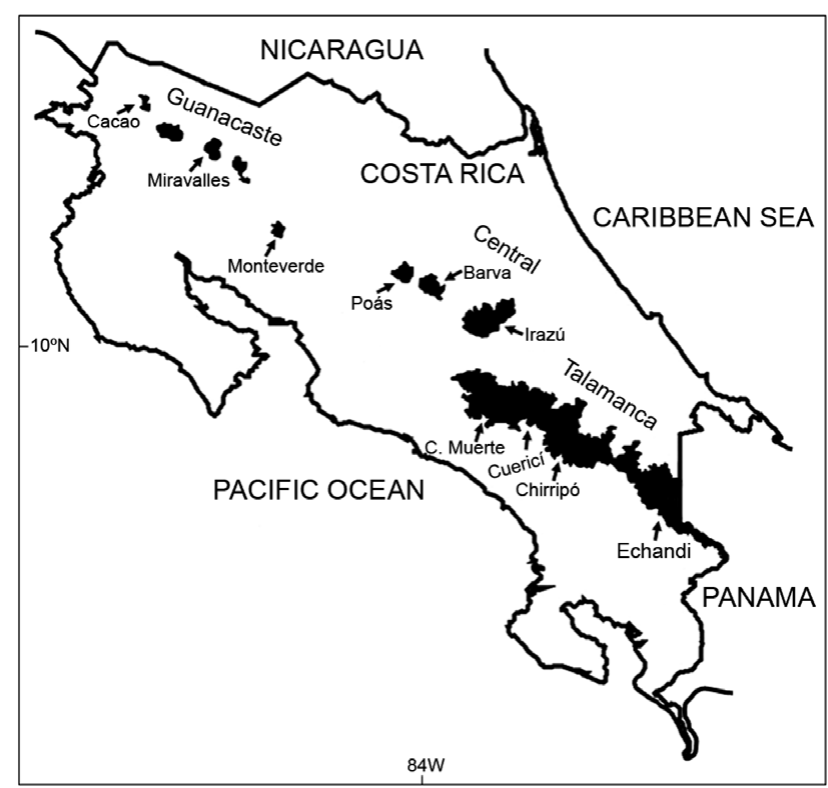

Figure 1. Study sites (indicated by black arrows) surveyed for this study along the four Costa Rican mountain ranges.

\section{METHODS}

\section{Field data collection}

We conducted bird surveys from December 1993 through January 2005 in highland forests of the four main mountain ranges in Costa Rica to estimate species richness: four sites in the Talamanca mountain range, three in the Central Volcanic mountain range, one in the Tilarán mountain range, and two in the Guanacaste mountain range (Figure 1). Sites included the highest peaks as well as the northern and southern limits of each mountain range, except in the Guanacaste mountain range where volcanic activity precluded sampling in a large portion of highland vegetation along its southern boundary. We visited each site from 7 to 20 times and during each visit we walked into the forest along available trails identifying all birds heard or seen. We additionally deployed 5-8 mist nets $(12 \times 2 \mathrm{~m})$ during each visit to capture secretive species that can be difficult to see or hear. The number of visits and surveying time was initially planned to be proportional to the area of available habitat for endemic highland species. However, we extended the surveys at each field site until no new species were recorded in at least three consecutive visits. Presenceabsence of species obtained with both survey methods was combined to obtain species richness for each site. For the analyses we combined all sites in the Talamancas since we did not detect any difference in species richness among sites (data not shown) and because there are no geographic discontinuities along this mountain range that are expected to prevent bird movement (Gómez 
Table 1. Highland sites visited in each Costa Rican mountain range and respective estimated areas (ha). Areas of all Talamanca sites were combined due to absence of geographic discontinuities.

\begin{tabular}{lr}
\hline Mountain range/locality & Area (ha) \\
\hline Talamanca & 153750 \\
Central & 15860 \\
Irazú & 5800 \\
Barva & 5545 \\
Poás & \\
Tilarán & 11970 \\
Monteverde & \\
Guanacaste & 2000 \\
Miravalles & 100 \\
Cacao & \\
\hline
\end{tabular}

1986). We did not sample birds in the highlands of western Panama; however the bird list reported by Ridgely \& Gwynne (1989) for those highlands is identical to our list from the southernmost extreme of Costa Rica.

\section{Statistical analysis}

We assessed the relationship between area of highland islands and species richness for endemic and non-endemic species separately using the linear regression for the island biogeography model: $\ln S=\ln \mathrm{c}+\mathrm{z} \ln \mathrm{A}$; where $S$ is the number of species estimated, $A$ is the area, and $c$ and $z$ are fitted constants that depend on the studied system (MacArthur \& Wilson 1967). Observed species number for each highland island was compared with species richness estimated by the model using a chi-square goodness-of-fit test. The area of each highland island (Table 1) was obtained from Barrantes \& Loiselle (2002).

We also determined whether endemic species composition across highland islands follows a nested distribution, or if each island contains an independent subset of species of the entire highland endemic avifauna. Island assemblages are considered to be nested when species found in assemblages from smaller islands are a subset of the species found on larger islands. We assessed nestedness by measuring deviation of the observed assemblage of species from a distribution of randomly constructed assemblages. According to Patterson \& Atmar (1986), deviation from perfect nestedness occurs when a given species is absent from richer assemblages summed over all species, so that nested assemblages have less deviation from perfect nestedness. In this study nestedness was assessed using the NODF (nestedness based on overlap and decreasing fill) metric proposed by Almeida-Neto et al. (2008), which improves the result of the temperature metric proposed by Atmar \& Patterson (1993). With this metric it is possible to decompose total nestedness (entire presence-absence matrix) into two components: the effect of sites (i.e. rows) and the effect of species (i.e. columns). The NODF metric was calculated for rows (i.e. sites) and for the entire matrix using the Vegan package (version 1.17; http://cran.r-project.org), implemented in the R Statistical Language (version 2.10; http://www.R-project.org). The statistical significance of the calculated metrics was assessed by contrasting the observed value to NODF estimates from 10000 simulated communities. We created simulated species assemblages using null models with the rl constraint (Wright et al. 1998). The $r 1$ model draws species for each site with probabilities based on the species' marginal frequencies, until the site's original richness is attained. Normal probability scores (two-tailed z-scores) were used to compare observed values to the distribution of simulated temperature values. Results were comparable when other null models (r00, r2, sensu Wright et al. 1998) were tested. This analysis was not applied to species that are not highland endemics, since distribution of these species is not fragmented throughout most of the country.

To infer the causality of nestedness we conducted the statistical analysis described by Lomolino (1996). This analysis assesses probability of two potential causal mechanisms for nestedness in insular communities: differential migration due to increased distance or barriers from a species source, and differential extinction due to a reduction in available habitat (Cutler 1991, Lomolino 1996, Patterson 1990, Patterson \& Atmar 1986). We calculated the statistics defined by Lomolino (1996): $\% \mathrm{PN}=100 \times(\mathrm{R}-\mathrm{D}) / \mathrm{R}$, where $\% \mathrm{PN}=\%$ of perfect nestedness, $\mathrm{R}=$ mean number of departures from random simulations and $\mathrm{D}=$ number of departures in the order matrix. The significance of the D statistic was obtained by comparing the calculated value to a distribution obtained from 1000 random permutations of the original matrix, using a function written in the $\mathrm{R}$ language (available upon request). Lomolino's statistics were calculated for two presence/absence species matrices. The first matrix ordered sites by area of available habitat with Talamanca as the largest site and Cacao volcano as the smallest (Figure 1). The second matrix ordered sites based on isolation with Talamanca as the most isolated and Barva volcano the least. Degree of isolation was defined as the vertical distance between the lower limit of the distribution of highland endemic species and the highest point of the mountain passes (or watersheds) between two adjacent highland islands. The first matrix tests the hypothesis that nestedness is caused by differential extinction, while the second considers differential migration as the causal factor of nestedness. We additionally tested nestedness causality using a different second matrix. This matrix ordered the sites by isolation caused by contraction of highland vegetation after the Pleistocene. Those mountains that first became separated as highland vegetation retreated were considered for this analysis more isolated than other mountains that became isolated later (Barrantes 2009). 


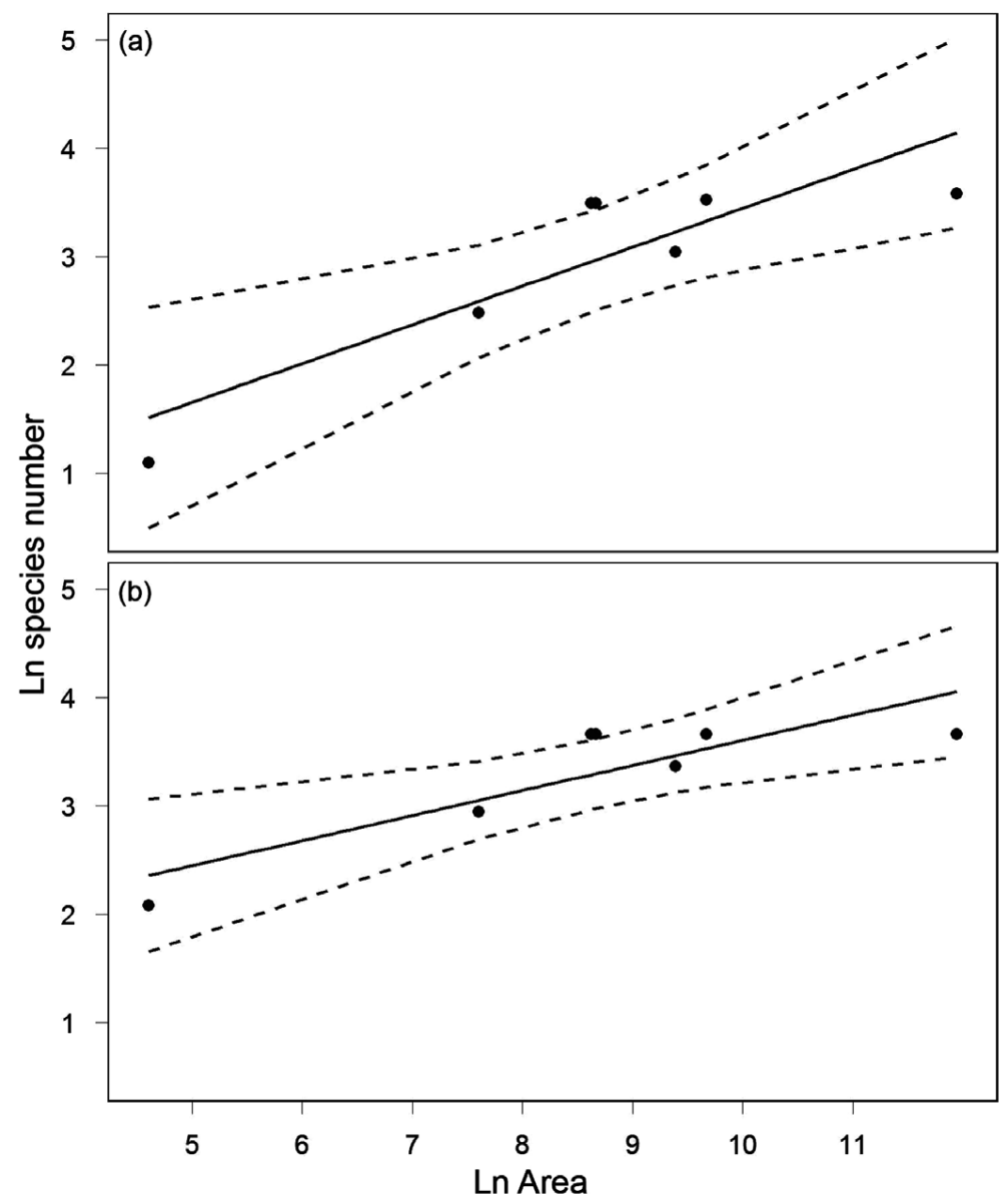

Figure 2. Relationship between area of available habitat and number of highland bird species (species number and area were ln-transformed). Number of endemic (a) and non-endemic (b) bird species sampled at different highland islands on the four mountain ranges in Costa Rica. Dotted lines show $95 \%$ confidence intervals for the regression line.

\section{RESULTS}

We recorded a total of 74 bird species, 36 highland endemic and 38 non-endemic species in the highlands of Costa Rica (Appendix 1). The number of species increased for endemics and non-endemics from Cacao volcano (Guanacaste mountain range) to the Talamanca mountain range (Figure 1). The change in species number was primarily correlated with the amount of available habitat area in each locality. For highland endemic species, changes in area explained $77 \%$ of the variance in species number across localities $\left(F_{1,5}=16.8, \mathrm{P}=0.009\right.$, $\mathrm{c}=-0.136, \mathrm{z}=0.358$; Figure 2). We obtained similar results for non-endemic species with $75 \%$ of the variance in species number across localities explained by a change in area $\left(F_{1,5}=16.8, \mathrm{P}=0.009, \mathrm{c}=1.291, \mathrm{z}=0.232\right)$. The slope was steeper for endemic species, though it did not differ significantly from that of non-endemics $\left(t_{10}=\right.$ $0.01, \mathrm{P}=0.98)$, nor from the slope $(\mathrm{z}=0.335)$ calculated by Vuilleumier \& Simberloff (1980) for species present in
23 paramo patches in South America $\left(t_{26}=0.001, \mathrm{P}=\right.$ $0.99, \mathrm{z}=0.334)$.

The difference between observed species number and the number predicted by the linear model (species-area relationship) varied across localities. In the Talamancas, the number of species was significantly lower than that predicted by the model $\left(\chi_{1}^{2}=11.6, \mathrm{P}=0.0006\right)$, whereas in Barva and Poás the number of species was higher than the number predicted by the model $\left(\chi_{1}^{2}=8.45\right.$, $\mathrm{P}=0.0034$; and $\chi_{1}^{2}=10.3, \mathrm{P}=0.0013$ respectively). At all other localities, species numbers did not deviate significantly from values predicted by the model.

The entire community of highland endemics showed a strongly nested pattern $(\mathrm{NODF}=78.0 ; \mathrm{z}=2.25 ; \mathrm{P}<$ $0.002)$. Sites also showed a similar pattern $\left(\mathrm{N}_{\text {sites }}=\right.$ 95.2, $\mathrm{z}=3.78, \mathrm{P}<0.0001$; Figure 3), indicating that the observed distribution of endemic species across the highland localities is congruent with a nested subset of communities. In this case, the Talamanca mountain range, with the largest area of available habitat, contained 


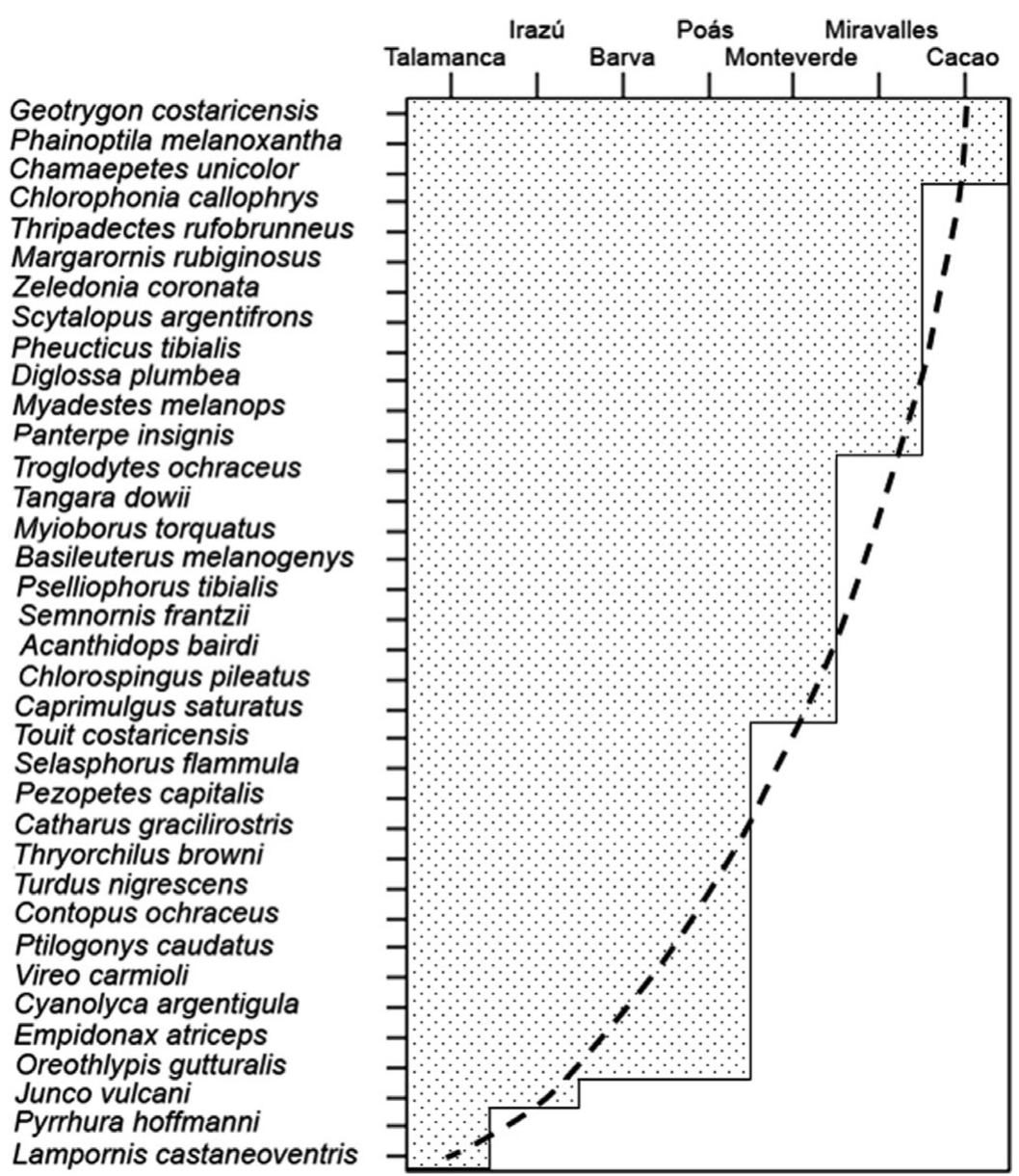

Figure 3. Nestedness plot with binary presence-absence of species in the ordinate and study sites in the abscissa. Species presence is shown as a shaded block, while absence is in white. The maximum incidence of species is shown on the upper left corner of the matrix and the dashed curved line is the fill line that indicates the distribution of species in a perfectly nested matrix.

all highland endemic species, whereas smaller highland islands toward the north-west contained smaller subsets of this avifauna (Table 1). Nestedness in this highland mountain system is more likely explained by differential extinction $(\mathrm{D}=12, \mathrm{R}=44.5, \mathrm{P}=0.01, \% \mathrm{PN}=73.0)$ than by differential migration due to current topographic barriers $(\mathrm{D}=39, \mathrm{R}=44.3, \mathrm{P}=0.368, \% \mathrm{PN}=12.0)$, or differential migration due to isolation caused by contraction of highland vegetation $(\mathrm{D}=33, \mathrm{R}=44.2$, $\mathrm{P}=0.233, \% \mathrm{PN}=25.4$ ).

\section{DISCUSSION}

Highland endemic birds present in the highlands of Costa Rica and western Panama have a stronger affinity with Andean species and to a lesser degree with Nearctic species (Barrantes 2009). This suggests that ancestral bird species probably dispersed from South and North America to Central America since the late Pliocene (Hackett 1995, Haffer 1974, Smith \& Klicka 2010, Stiles 1983a, Winker \& Pruett 2006). Ancestral population dispersal was likely favoured during glacial peaks, when vegetation currently typical of the highlands extended to lower elevations, but dispersal routes were later severed during interglacial periods. As climate became gradually more tropical during interglacial periods (e.g. after the Pleistocene), arrival of new species was reduced, isolating the Central American highlands from the Nearctic region and from South American mountains, promoting speciation in Costa Rican and western Panamanian mountains (Barrantes 2009, Hackett 1995, Haffer 1974, Winker \& Pruett 2006).

The number of highland endemic and non-endemic bird species present in the Costa Rican highlands is significantly affected by the area of highland islands. Despite our small sample size, dictated by the geographic characteristics of the system studied, the effect of area on the number of species is comparable with that obtained by Vuilleumier \& Simberloff (1980) in a much more extensive geographic area in South American highlands. They found nearly the same effect of area on the number of paramo species present in 23 patches, indicating that similar processes (e.g. extinction imposed by habitat 
reduction over interglacial periods during and after the Pleistocene, or differential migration due to the effects of barriers) may have similar effects on independent bird communities. However, our results should be viewed with caution, since each point (locality) in a small sample size, particularly extreme values (e.g. Cacao, Barva, Poás), may strongly affect the significance of the species-area relationship.

Within Costa Rican mountain ranges, the assemblages of highland endemic species across disjunct highland islands follow a spatially nested distribution. Endemic species found in the most depauperate isolated areas located in the north-west part of the country (e.g. Guanacaste and Tilarán, Figure 1) are present in progressively more species-rich islands. These islands have progressively larger areas towards the south-east part of the country, with the Talamanca mountain range containing all highland endemic species. This nested pattern in these assemblages of highland bird species is more likely the result of differential extinction due to a reduction of available habitat, rather than a consequence of limited migration.

Our results are also congruent with the hypothesis proposed by Barrantes (2009) to explain the general distribution of endemic species in the highlands of Costa Rica and western Panama. This hypothesis is based on the reconstruction of highland vegetation using fossil pollen from the Dryas stadial (c. 18000 ya; Hooghiemstra et al. 1992, Islebe et al. 1995, 1996), and proposes that highland vegetation and highland avifauna had a continuous distribution from western Panama to the northernmost extreme mountains in Costa Rica during glacial periods. During interglacial periods, as the climate turned progressively more tropical, the distributions of highland bird species contracted and became confined to the upper elevations of mountain ranges as highland vegetation withdrew to higher altitudes where climatic conditions were more favourable. The progressive reduction in available habitat probably also led to a progressive increase in the extinction rate of the birds associated with highland vegetation. Extinction was apparently higher on isolated mountain peaks with relatively low elevation, where available habitat for endemic birds covers only a small area around the summit. Our analyses strongly suggest that changes in habitat availability produced by climatic shifts in the late (and after) Pleistocene was an important factor shaping current bird species assemblages in southern Central America.

Local extinction has been proposed to be a primary factor shaping nested patterns of species distribution in naturally isolated areas, such as archipelagos and isolated areas on mountain tops in different regions worldwide (Brown 1971, Martínez-Morales 2005, Mayr \& Diamond 2001, Patterson \& Brown 1991, Worthen 1996, Wright et al. 1998). The evidence obtained in this study supports the hypothesis of extinction, rather than restricted migration, to explain the current pattern of nested species assemblages in the highlands of Costa Rica. This mountain system represents a unique opportunity to study the effects of isolation on morphological, genetic and behavioural (e.g. song) divergence, and which may reflect incipient speciation in a large number of species confined to small geographic areas (Barrantes \& Sánchez 2000, Chavarría et al. 2010). Our results are of particular interest as present global climate changes may have an impact on the vegetation structures in highland mountains and further reduce the available habitat for endemic highland bird species (Pounds et al. 1999).

\section{ACKNOWLEDGEMENTS}

We are grateful to Johel Chaves-Campos, Jessica Eberhard, Jeffrey Ross-Ibarra and an anonymous reviewer for constructive comments that greatly improved the manuscript, Julio Sánchez for collaboration in the field, and Federico Valverde for logistical support. Financial support was provided by Vicerrectoría de Investigación, Universidad de Costa Rica.

\section{LITERATURE CITED}

ALMEIDA-NETO, M., GUIMARÃES, P., GUIMARÃES, P. R., LOYOLA, R. D. \& ULRICH, W. 2008. A consistent metric for nestedness analysis in ecological systems: reconciling concept and measurement. Oikos 117:1227-1239.

AMERICAN ORNITHOLOGISTS' UNION. 1998. Check-list of North American birds, 7 th edition and its supplements. American Ornithologists' Union, Washington. 829 pp.

ATMAR, W. \& PATTERSON, B. D. 1993. The measure of order and disorder in the distribution of species in fragmented habitat. Oecologia 96:373-382.

BARRANTES, G. 2005. Aves de los páramos de Costa Rica. Pp. 521-532 in Kappelle, M. \& Horn, S. P. (eds.). Páramos de Costa Rica. Instituto Nacional de Biodiversidad, Heredia, Costa Rica.

BARRANTES, G. 2009. The role of historical and local factors in determining species composition of the highland avifauna of Costa Rica and western Panamá. Revista de Biología Tropical 57(Suppl. 1):333-349.

BARRANTES, G. \& LOISELLE, B. 2002. Reproduction, habitat use, and natural history of the Black-and-Yellow Silky-Fly Catcher (Phainoptila melanoxantha), an endemic bird of the Western Panamá-Costa Rica Highlands. Ornitologia Neotropical 15;121-136.

BARRANTES, G. \& SÁNCHEZ, J. 2000. A new subspecies of Black and Yellow Silky Flycatcher, Phainoptila melanoxantha (Bombycillidae, Aves), from Costa Rica. Bulletin of the British Ornithologists' Club $120 ; 40-46$.

BROWN, J. H. 1971. Mammals on mountaintops: non-equilibrium insular biogeography. American Naturalist 105:467-478.

CHAVARRÍA-PIZARRO, T., GUTIÉRREZ-ESPELETA, G., FUCHS, E. J. \& BARRANTES, G. 2010. Genetic and morphological variation of 
the sooty-capped bush tanager (Chlorospingus pileatus), a highland endemic species from Costa Rica and western Panama. Wilson Journal of Ornithology 122:279-287.

CUTLER, A. 1991. Nested faunas and extinction in fragmented habitats. Conservation Biology 5:496-504.

FJELDSÅ, J. 1992. Biogeography of the birds of the Polylepis woodlands of the Andes. Pp. 31-44 in Balslev, H. \& Luteyn, J. L. (eds.). Paramo: an Andean ecosystem under human influence. Academic Press, London.

FJELDSÅ, J. \& KRABBE, N. 1990. Birds of the high Andes. Zoological Museum of Copenhagen and Apollo Books, Svendborg. 876 pp.

GÓMEZ, L. D. 1986. Vegetación de Costa Rica. Apuntes para una biogeografía costarricense. Universidad Estatal a Distancia, San José. 327 pp.

HACKETT, S. J. 1995. Molecular systematics and zoogeography of flowerpiercers in the Diglossa baritula complex. Auk 112:156170.

HAFFER, J. 1974. Avian speciation in tropical South America. Nuttall Ornithological Club 14:1-390.

HOOGHIEMSTRA, H., CLEEF, A. M., NOLDUS, G. \& KAPPELLE, M. 1992. Upper Quaternary vegetation dynamics and palaeoclimatology of the La Chonta bog area (Cordillera de Talamanca, Costa Rica). Journal of Quaternary Science 7:205-225.

ISLEBE, G. A., HOOGHIEMSTRA, H. \& VAN DER BORG, K. 1995. A cooling event during the younger Dryas Chron in Costa Rica. Palaeogeography, Palaeoclimatology, Palaeoecology 117:73-80.

ISLEBE, G. A., HOOGHIEMSTRA, H. \& VAN VEER, R. T. 1996. Holocene vegetation and water level history in two bogs of the Cordillera de Talamanca, Costa Rica. Vegetatio 124:155-171.

LOMOLINO, M. V. 1996. Investigating causality of nestedness of insular communities: selective immigrations or extinctions? Journal of Biogeography 23:699-703.

LOWELL, T. V., HEUSSER, C. J., ANDERSEN, B. G., MORENO, P. I., HAUSER, A., SCHLUCHTER, C., MARCHANT, D. R. \&DENTON, G. H. 1995. Interhemispheric correlation of late Pleistocene glacial events. Science 269:1541-1549.

MACARTHUR, R. H. \& WILSON, E. O. 1967. The theory of island biogeography. Princeton University Press, Princeton. 203 pp.

MARTÍNEZ-MORALES, M. A. 2005. Nested species assemblages as a tool to detect sensitivity to forest fragmentation: the case of cloud forest birds. Oikos 108:634-642.

MAYR, E. \& DIAMOND, J. 2001. The birds of the northern Melanesia. Speciation, ecology, and biogeography. Oxford University Press, New York. 492 pp.

NORES, M. 1995. Insular biogeography of birds in mountain tops of north western Argentina. Journal of Biogeography 22:61-70.

PATTERSON, B. D. 1990. On the temporal development of nested subset patterns of species composition. Oikos 59:330-342.

PATTERSON, B. D. \& ATMAR, W. 1986. Nested subsets and the structure of insular mammalian faunas and archipelagos. Biological Journal of the Linnean Society 28:65-82.

PATTERSON, B. D. \& BROWN, J. H. 1991. Regionally nested patterns of species composition in granivorous rodent assemblages. Journal of Biogeography 18;395-402.

PÉREZ-EMÁN, J. L. 2005. Molecular phylogenetics and biogeography of the Neotropical redstarts (Myioborus; Aves, Parulinae). Molecular Phylogenetics and Evolution 37:511-528.
POUNDS, J. A., FOGDEN, M. P. L. \& CAMPBELL, J. H. 1999. Biological response to climate change on a tropical mountain. Nature 398:611615.

PRANCE, G. T. 1982. A review of the phytogeographic evidences for Pleistocene climate changes in the Neotropics. Annals of the Missouri Botanical Garden 69:594-624.

PUEBLA-OLIVARES, F., BONACCORSO, E., ESPINOSA DE LOS MONTEROS, A., OMLAND, K. E., LLORENTE-BOUSQUETS, J. E., PETERSON, A. T. \& NAVARRO-SIGÜENZA, A. G. 2008. Speciation in the emerald toucanet (Aulacorhynchus prasinus) complex. Auk 125:39-50.

RIDGELY, R. S. \& GWYNNE, J. A. 1989. A guide to the birds of Panama, with Costa Rica, Nicaragua, and Honduras. Princeton University Press, Princeton. 412 pp.

ROSENZWEIG, M. L. 1995. Species diversity in space and time. Cambridge University Press, Cambridge. 436 pp.

SIMBERLOFF, D. \& ABELE, L. G. 1982. Refuge design and island biogeographic theory: effects of fragmentation. American Naturalist 120:41-50.

SLUD, P. 1964. The birds of Costa Rica. Distribution and ecology. Bulletin of the American Museum of Natural History 128:1-430.

SMITH, B. T. \& KLICKA, J. 2010. The profound influence of the Late Pliocene Panamanian uplift on the exchange, diversification, and distribution of New World birds. Ecography 33:333-342.

STILES, F. G. 1983a. Birds. Introduction. Pp. 502-530 in Janzen, D. (ed.). Costa Rican natural history. Chicago University Press, Chicago.

STILES, F. G. 1983b. Systematics of the southern forms of Selasphorus (Trochilidae). Auk 100:311-325.

STILES, F. G. 1985. Geographic variation in the Fierythroated Hummingbird, Panterpe insignis. Ornithological Monographs 36:2330.

STILES, F. G. \& SKUTCH, A. F. 1989. A guide of the birds of Costa Rica. Cornell University Press, Ithaca. 511 pp.

VUILLEUMIER, F. 1970. Insular biogeography in continental regions. I. The northern Andes of South America. American Naturalist 104:373388.

VUILLEUMIER, F. \& SIMBERLOFF, D. 1980. Ecology versus history as determinants of patchy and insular distributions in high Andean birds. Evolutionary Biology 12:235-379.

WEIR, J. T. 2006. Divergent timing and patterns of species accumulation in lowland and highland Neotropical birds. Evolution 60:842-855.

WHITTAKER, R. J., TRIANTIS, K. A. \& LADLE, R. J. 2008. A general dynamic theory of oceanic island biogeography. Journal of Biogeography 35:977-994.

WINKER, K. \& PRUETT, C. L. 2006. Seasonal migration and morphological convergence in the genus Catharus (Turdidae). Auk 123:1052-1068.

WOLF, L. L. 1976. Avifauna of the Cerro de la Muerte region Costa Rica. American Museum Novitates 2606:1-37.

WORTHEN, W. B. 1996. Community composition and nested-subset analyses: basic descriptors for community ecology. Oikos 76:417426.

WRIGHT, D. H., PATTERSON, B. D., MIKKELSON, G. M., CUTLER, A. \& ATMAR, W. 1998. A comparative analysis of nested subset patterns of species composition. Oecologia 113:1-20. 
Appendix 1. Distribution range between Talamanca and the northernmost extreme of endemic and nonendemic bird species sampled at different mountains on the highlands of Costa Rica. Nomenclature and order of species follow the American Ornithologists' Union (1998) and supplements. Talam, Talamanca; Mirav, Miravalles; Montev, Monteverde.

\begin{tabular}{|c|c|c|c|}
\hline \multicolumn{2}{|c|}{ Endemic species } & \multicolumn{2}{|c|}{ Non-endemic species } \\
\hline Family/species & Distribution & Family/species & Distribution \\
\hline \multicolumn{2}{|l|}{ Cracidae } & \multicolumn{2}{|l|}{ Tinamidae } \\
\hline Chamaepetes unicolor & Talam-Cacao & Nothocercus bonapartei & Talam-Mirav \\
\hline \multicolumn{2}{|l|}{ Columbidae } & \multicolumn{2}{|l|}{ Odontophoridae } \\
\hline Geotrygon costaricensis & Talam-Cacao & Dendrortyx leucophrys & Talam-Poás \\
\hline \multicolumn{2}{|l|}{ Psittacidae } & Odontophorus guttatus & Talam-Poás \\
\hline Pyrrhura hoffmanni & Talam & \multicolumn{2}{|l|}{ Cathartidae } \\
\hline Touit costaricensis & Talam-Poás & Coragyps atratus & Talam-Cacao \\
\hline \multicolumn{2}{|l|}{ Caprimulgidae } & Cathartes aura & Talam-Cacao \\
\hline Caprimulgus saturatus & Talam-Montev & \multicolumn{2}{|l|}{ Accipitridae } \\
\hline \multicolumn{2}{|l|}{ Trochilidae } & Elanoides forficatus & Talam-Mirav \\
\hline Panterpe insignis & Talam-Mirav & Leucopternis princeps & Talam-Mirav \\
\hline Lampornis castaneoventris & Talam & Buteo jamaicensis & Talam-Montev \\
\hline Selasphorus flammula & Talam-Poás & Spizaetus ornatus & Talam-Montev \\
\hline \multicolumn{2}{|l|}{ Semnornithidae } & Spizaetus melanoleucus & Talam-Mirav \\
\hline Semnornis frantzii & Talam-Montev & \multicolumn{2}{|l|}{ Columbidae } \\
\hline \multicolumn{2}{|l|}{ Furnariidae } & Patagioenas fasciata & Talam-Cacao \\
\hline Margarornis rubiginosus & Talam-Mirav & Patagioenas subvinacea & Talam-Montev \\
\hline Thripadectes rufobrunneus & Talam-Mirav & Claravis mondetoura & Talam-Poás \\
\hline \multicolumn{2}{|l|}{ Rhinocryptidae } & \multicolumn{2}{|l|}{ Psittacidae } \\
\hline Scytalopus argentifrons & Talam-Mirav & Bolborhynchus lineola & Talam-Poás \\
\hline Tyrannidae & & Strigidae & \\
\hline Contopus ochraceus & Talam-Poás & Megascops clarkii & Talam-Mirav \\
\hline Empidonax atriceps & Talam-Poás & Aegolius ridgwayi & Talam-Poás \\
\hline Vireonidae & & Apodidae & \\
\hline Vireo carmioli & Talam-Poás & Streptoprocne zonaris & Talam-Cacao \\
\hline Corvidae & & Trochilidae & \\
\hline Cyanolyca argentigula & Talam-Poás & Colibri thalassinus & Talam-Montev \\
\hline Troglodytidae & & Trogonidae & \\
\hline Troglodytes ochraceus & Talam-Montev & Trogon collaris & Talam-Poás \\
\hline Thryorchilus browni & Talam-Poás & Pharomachrus mocinno & Talam-Montev \\
\hline Turdidae & & Ramphastidae & \\
\hline Myadestes melanops & Talam-Mirav & Aulacorhynchus prasinus & Talam-Cacao \\
\hline Catharus gracilirostris & Talam-Poás & Picidae & \\
\hline Turdus nigrescens & Talam-Poás & Melanerpes formicivorus & Talam-Poás \\
\hline Ptilogonatidae & & Picoides villosus & Talam-Montev \\
\hline Phainoptila melanoxantha & Talam-Cacao & Furnariidae & \\
\hline Ptilogonys caudatus & Talam-Poás & Pseudocolaptes lawrencii & Talam-Mirav \\
\hline Parulidae & & Lepidocolaptes affinis & Talam-Mirav \\
\hline Oreothlypis gutturalis & Talam-Poás & Tyrannidae & \\
\hline Myioborus torquatus & Talam-Montev & Elaenia frantzii & Talam-Mirav \\
\hline Basileuterus melanogenys & Talam-Montev & Zimmerius vilissimus & Talam-Montev \\
\hline Zeledonia coronata & Talam-Mirav & Mitrephanes phaeocercus & Talam-Mirav \\
\hline Thraupidae & & Incertae sedis & \\
\hline Chlorospingus pileatus & Talam-Montev & Pachyramphus versicolor & Talam-Montev \\
\hline Tangara dowii & Talam-Montev & Cotingidae & \\
\hline Emberizidae & & Procnias tricarunculatus & Talam-Mirav \\
\hline Acanthidops bairdi & Talam-Montev & Hirundinidae & \\
\hline Diglossa plumbea & Talam-Mirav & Pygochelidon cyanoleuca & Talam-Cacao \\
\hline Pselliophorus tibialis & Talam-Montev & Troglodytidae & \\
\hline Pezopetes capitalis & Talam-Poás & Troglodytes aedon & Talam-Cacao \\
\hline Junco vulcani & Talam-Irazú & Henicorhina leucophrys & Talam-Cacao \\
\hline Cardinalidae & & Emberizidae & \\
\hline Pheucticus tibialis & Talam-Mirav & Haplospiza rustica & Talam-Montev \\
\hline Fringillidae & & Zonotrichia capensis & Talam-Mirav \\
\hline Chlorophonia callophrys & Talam-Mirav & Cardinalidae & \\
\hline & & Piranga bidentata & Talam-Poás \\
\hline & & Icteridae & \\
\hline & & Amblycercus holosericeus & Talam-Mirav \\
\hline & & Fringillidae & \\
\hline & & Spinus xanthogastra & Talam-Poás \\
\hline
\end{tabular}

